\title{
The Roles of Federal Government and Security Challenges of Boko Haram in Nigeria
}

\section{Charles Chukwuma Nwoba}

Odoh Stella

\author{
Social Studies Department \\ Ebonyi State College of Education, Ikwo-Nigeria
}

\section{Doi:10.5901/jesr.2013.v3n10p19}

\begin{abstract}
The thrust of this paper is to know the roles of Federal Government towards insurgency of Boko Haram. It had been a source of worry to commentators, observers and scholars on insecurity visà-vis activities of Islamic extremists in the North-east. The area had witnessed wanton destruction of lives and property which had been on increase. It had affected socio- economic and political life of the people which led to Declaration of State of Emergency. International Organizations, Human Rights activists, individuals, had been pointing accusing fingers on Federal Government, on inability to Stop Human Rights Violation. This work $x$-rays the roles of Federal Governments to end the insurgency. The paper argues, if unguided utterances, derogatory statements and hidden interests are not thoroughly checked, instead of ameliorating, will be adding salt to injury. And advocated for honesty and dialogue for unity in Nigeria.
\end{abstract}

Keywords: Boko Haram, Challenges, Roles, Federal Government, Security

\section{Introduction}

\subsection{Meaning of the Concept "Boko Haram"}

The concept of Boko Haram had its origin from Islamic fundamentalist. Boko Haram means "Western Education is Forbidden or Sinful" Ogbonnaya (2015). It base in Nigeria is North-east of the country and worst heated areas include: Borno, Yobe and Adamawa.This led to declaration of State of Emergency by President Jonathan. World News (2013). Others areas slightly affected include Kaduna, Benue, Plateau, and Kano. The jihadists group frown at non- Sharia Legal System and sees westernized Education and Culture as crime as they believed to be corrupting Muslims opposing the Islamic creed. France (2011). The Islamic movement turned to armed militant terrorist believed to have wasted many lives and property in the country. I ts effects outweighed the initial Religious crisis previously experienced in the region.

\section{Historical Review of the Concept "Boko Haram"}

Boko Haram is an insurgence that is not very new in Nigeria. It origin dates backs from 1995 when it was called Shabaab Muslim Youth; Mallam Lawal was at the helms of affairs when he left to further his education. Mohammed Yusuf took over as the head of the group. His leadership exposed the group to political influence and cheap popularity Takofraija (1970). .Later in 2009, Boko Haram was founded as indigenous group (jihadist group) David (2011). With the attitude of winners takes all by most Nigerian politicians they were abandoned after elections. It metamorphosed to evil wind that blows no one any good in the country till date. The true situation 
in the Northeast of the country is that high magnitude of damage of lives and property in very alarming with bloodletting and mayhem. This led to the caution of US secretary that the Nigeria Army should show restraint and not violate Human Rights as it pursues the militants, Osewa (2013). He further noted that, "there were credible allegations of gross Human Rights Violations by the Nigeria military" In the same vain, the Africa Program Director for international Crisis Group Sis. Comfort Ero noted that,"Today there are no boundaries and they are targeting the civilian population in a way that shows Nigeria is in a dangerous turning point," Ero (2013). Adding her voice, the Ambassador Wendy Shema of the US Bi-National Commission Regional Security Cooperation Working Group in Abuja, said that, "the problem of insurgence remains the greatest challenge to Nigeria development presently" AFP (2013). Therefore, the damages are unquantifiable, though it was estimated at the end of third quarter of 2013 , that over 3,600 lives were lost in the menace of Boko Haram insurgency and the Nigerian military that lunched offensive in the area but were accused of Human Rights abuses. World News (2013).

\section{Claimed Objectives of the Islamic Jihadist Militants Terrorist Called Boko Haram}

1. to create an Islamic States in the country

2. to achieve its anti-Western Education target.

3. to fight for provision of job to the unemployed Youths in the region

4. to fight for poverty reduction as over $75 \%$ live below poverty level of one dollar per person in the region. World news (2013)

The above reasons seem to be the objectives of the Boko Haram Islamic Sect but the militants group has been accused of having other hidden agenda to Islamize Nigeria and for power shift in 2015 to the North.

\section{Target of the Boko Haram Sect}

From evidence available based on the operation of the insurgent the mostly heated areas as their target includes: churches, markets, government public and private institutions, security agencies, forests, hills/caves, roads, homes buildings and in extreme cases mosques.

\section{Instruments Used For Operation by Boko Haram}

The Boko Haram members use the under listed weapons to carry out their operations and attacks on the people. For example, commander-in-charge of JTF in Kano Brigadier-General Illayaasu Abba, "enumerated items recovered from the insurgents as follows; ...assault rifles, twoAK58Rifle magazines, with 193 round of $5.56 \mathrm{~mm}$ ammunition, one AK-47 rifle magazine with 107 rounds of $7.62 \mathrm{~mm}$ special ammunition as well as bows and arrows, three primed cylinders, 24 detonators small bags of fertilizers IED IMERS cortex wires and three remote control garget, Motorola hand radios, four communicators, six alarm clocks, two cartons of 9 volt batteries, one scale, one heavy duty charger/battery" said commander-in-charge of JTF in Kano. ICC (2013). Other dangerous instruments include; Bombs, Heavy artillery, Strafing, Cutlasses, Daggers, Disguise in military uniform (JTF), gun of different varieties and motorbikes.

\section{Roles of Federal Government to End the Insurgence Of Boko Haram Militancy In Nigeria}

1. Declaration of State of emergency in three local Governments in 2011 and another State of Emergency in 15 May, 2013 at three States namely, Borno, Yobe and Adamawa by President Goodluck J onathan.

2. Training of 9,000 Soldiers at once for six month, "it is a security strategy by the Army to 
contain the increasing wave of terrorism and other crimes that threatens the nation" and "the training involves heavy financial costs which was described as necessary cost to save guide the nation. kilete (2013)

3. "... the establishment of 7 Division of the Nigeria Army in Borno, to take charge of security operation in the north east", said Chief of Army Staff Lt-Gen.Azubuike Iheejirika. He further stated, "that Problem of difficulties of transportation of the troops from 3 division of Nigerian Army from Maiduguri to Jos ad-hoc JTF arrangement was not sufficient to deal with the magnitude of the problem it was confronting ... procurements of Arms and ammunition"

4. On May 21, 2013, the Nigerian President ordered the release of women and children held in connection with the terrorist activities, says the defense minister

5. The J oint Task Force initiated the Formation of vigilantes Group called, "Civilian J oint Task Force".

6. Setting up of Committee on Dialogue and Peace Resolution of Security Challenges in the North Chaired by Defense Minister Tanimu Tuuraki

7. Dialogue and open talk with the group: this disclosed that the group had decided to enter into genuine peace negotiation with the government based on the tenant of Islam, the teaching of Prophet Mohammed and the writing of the eminent Islamic Scholars and Jurists according to the Peace Resolution Committee.

8. Federal Government directive to Security Exchange Commission which reads thus; "All capital market operators are by this letter required to check their database for the names", "Jamatu Ahlis-Sunna Liddaawati Wai J ihad" otherwise known as "Boko Haram" sect and Jama'atu Ansarul Muslimina Fishermen Biladis Sudan" as well as their association and report same to the Securities and Exchange Commission. Where no business relationship is maintained for any of the proscribed names or their associations, a nil return should be rendered," the apex regulator stated. (Salako 2013)

9. Director General of Security and exchange Commission (SEC), Ms Aruma Oteh had recently inaugurated Committee of Chief compliance Officers in the capital Market with the primary responsibility of preventing the injunction of illegal funds or proceed of criminal acts into the capital market.(Salako 2013).

10. Handing over the suspected detained terrorist to the state government of the affected State for rehabilitation

11. Opened opportunity for freedom and dialogue for the suspected terrorists

12. Military offensive, air strike over 2000 soldiers were deployed to the troubled region to enhance peace efforts.

13. The Federal Government directed the blockage of cellophone services in the troubled areas in the Northeast namely: Borno, Yobe and Adamawa (UPI 2013).

14. Air Force enlightenment campaign in the barrack on the operation tips and mode of terrorist by the NADF at schools by the Director Air Provost Marshall Air Commodore, Nojeed Sanusi

15. Frequent change of posting of Nigeria Army to avert illegal deals

\section{Effects of Boko Haram Terrorist Attacks In Nigeria}

- scares away investors in the country

- creates widespread of insecurity in the country

- greatest Challenge to Nigeria development

- increases tension among the ethnic groups in the country

- it creates fear and generate tension in Nigeria Northern Neighbors

- it increases the socio-economic and political crisis of the nation

- protest over killing of JTF Civilians by Policeman members in Borno State 
- Students flee over the rumour of planned attacks in Bauchi by Boko Haram eg Federal Polytechnic in Gwalameji and the attack (burtal killing) of students of College of Agriculture Gujba tn Yobe Boko harm insurgents

\section{Details of Attack of Boko Haram and Military Offensive in the Northeast of Nigeria}

The extent of attacks of both the Boko Haram and the military offensive to the insurgence in the Northeast region is extensively illustrated in the appendix (Table 1a and 1b).

\section{Funding of Boko Haram In Nigeria}

For now there no officially established sources of revenue of the Boko haram jihadist group in Nigeria. Though, Federal government has tried to close some sources. For example, "Securities and exchange Commission (SEC), directed all the capital market operators to review their data base and check for any transactions involving entities and individuals related to proscribed extremist groups, especially Borno -based "boko haram"' ...the aim was to ensure compliance with proscription orders on some persons and organizations and also global and national anti-money laundering laws.(Salako,2013). Other sources may include disgruntled politicians, financial assistance from sis, Taliban, El-Quad a groups internationally and money got during looting of peoples property during some attacks.

\section{Recommendations}

1. Recalcitrant leaders should be brought to justice in consonance with the laws of the Land.

2. Dialogue should be encouraged.

3. Victims of the unfortunate insurgency should be adequately compensated by the governments at different levels.

4. Members of the sect should be made to face the music in the court of law in the country.

5. The borders should be seriously checkmated by the hiring foreign securitymen to avert the incidents of proliferation of arms and ammunitions in the country.

6. Sources of funding should be made known and closed

7. Stakeholders aiding and abating the insurgence should be exposed and disgraced publicly and jailed.

8. Employment opportunities should be created though functional entrepreneurship.

9. Nigeria should abstain from guided democracy.

10. The National Conference/dialogue should not be hijacked by greedy and self-centered politicians and while culture, religion and resources as bases for tolerance should be adequately addressed, and defined in the Conference.

11. Political leaders of different wards, communities, Villages, local governments and State apparatus should be held responsible for violence in their areas and forced to give account of the stewardship in their areas to end the scourge of Boko Haram in Nigeria.

12. The security collaborative efforts with border nations should be intensified

13. The standard of living of the people living in the borders communities should be increased by provision of infrastructures/amenities to avoid proliferation of arms and ammunitions in the area

14. Uncomplimentary remarks and deregulatory statements should be seriously checked, and lawfully punished, dialogue remains the best option.

\section{Conclusion}

The truth is that the situation in the North-east cannot be handled by standing akimbo. The nature 
of the fighting or expressing annoyance in this regards is not the solution to Nigerian unity. The use of physical and unjustified force approach, to violate, harm, damage, and destroy the future of innocent Nigerian citizens is a crime and threat to the existence of humanity. The out come of the warfare and uncontrollable force of Islamic extremists' boko haram on whatever cause they are defending is extremely destructive with its intimidating emotional effects. Therefore, to be proactive, formal discussion and negotiation, as part of transformation agenda should apply, style to apply not withstanding, should commence because the Nigerian population is being reduced everyday for unjustified reasons to avert the overwhelming fear being intensified in the region by the militant group called Boko Haram. Since, the group is illegal and terror based and even condemned by notable Muslims and Northern leaders.

\section{References}

Ogbonna 0.(2011), Boko Haram is battle for 2015, says Chukwumerije. The Nation, 29 September Molly K.(2013) Boko haram: Nigeria Army Depot, Trains 9000 Soldiers. Dailysun Wednesday October 16, (burmeserc21@gamail.com) p.37 www.sunnewsonline.com ...

France (2011), Boko Haram, Rocking the Nigeria Boat, France 2424 Decemer, 2011 Retrieved on

World News (2015), 29 Students teacher die in militant attack on Nigeria school Sky News July, 6 UPI UnitedPress International Genesis Training and changing Tactics of Boko Haram Revealed, Takofaija,com, 29 january, 1970 dead link Retrieved..

Cook D. (2011), The Rise of Boko Haram in Nigeria, combating Terrorism Centre. Retrieved....2012/07/12 "http://en. wikipedia.org/w/index. php?title=Boko Haram\&0ld=570146958"

Oluwaseun O. (2013), Boko Haran Crisis Nigeria to free Women politicsNarialand may 16,

News 24 Abuja, (2013), B0k0 haramtarget civilians in Nigeria. AFP August

AFP (2013), Two Boko Haram attacks killed 24 in Nigeria, August, 27

World news (2013), 25 killed by book haram sect in Nigeria, August 28, retieved

Salako T (2013), SEC searches Capital Market For Boko Haram' Funds, Launderers. The Nation September, 02

\section{Appendix}

Table 1a: Attacks by Boko Haram and Military Offensive in Northeast of Nigeria

\begin{tabular}{|c|c|c|c|c|}
\hline$s / n$ & Date & Place & incidents & remarks \\
\hline 1 & $7 / 09 / 10$ & Bauchi prison & Frees 721 inmates & \\
\hline 2 & $31 / 12 / 10$ & Abuja & Market blast & \\
\hline 3 & $22 / 04 / 11$ & Yola, Adamawa & Frees 14 inmates & \\
\hline 4 & $29 / 05 / 11$ & North & Bombs after inauguration & \\
\hline 5 & $16 / 5 / 11$ & Abuja & Police Headquarters bombing & \\
\hline 6 & $26 / 05 / 11$ & Maiduguri beer garden & Bombing & 25 dead \\
\hline 7 & $10 / 07 / 11$ & $\begin{array}{l}\text { All Christian Fellowship } \\
\text { Church Suleja }\end{array}$ & Bombing & \\
\hline 8 & $11 / 07 / 11$ & University of Maiduguri & Citing security concern & \\
\hline 9 & $12 / 08 / 11$ & & Killed Muslim Cleric & Liman Bnna dead \\
\hline 10 & $26 / 08 / 11$ & Abuja & bombing & \\
\hline 11 & $4 / 09 / 11$ & Damaturu & attack & \\
\hline 12 & $25 / 12 / 11$ & Nigeria & bombing & \\
\hline 13 & $5-6 / 01 / 12$ & Nigeria & attack & \\
\hline 14 & $20 / 01 / 12$ & kano & bombing & \\
\hline 15 & $28 / 01 / 12$ & Nigeria Army & Boko Hara members killed & 11 dead \\
\hline 16 & $8 / 02 / 12$ & Kaduna & Suicide bombing Army Headquarters & \\
\hline 17 & $16 / 02 / 12$ & Central Nigeria & Prison Break & $\begin{array}{l}119 \text { inmates frees and } \\
1 \text { warden died }\end{array}$ \\
\hline 18 & $8 / 03 / 12$ & British hostage & $\begin{array}{c}\text { Franco Lamolinara and Briton Choistopher } \\
\text { were killed }\end{array}$ & $\begin{array}{c}2 \text { foreigners were } \\
\text { killed }\end{array}$ \\
\hline
\end{tabular}




\begin{tabular}{|c|c|c|c|c|}
\hline 19 & $31 / 05 / 12$ & JTF & 5 sect members killed 1 German killed & One foreigner died \\
\hline 20 & $03 / 05 / 12$ & Bauchi & 15 Church Goers killed & Several injured \\
\hline 21 & $17 / 05 / 12$ & Kaduna & Suicide bombers & $\begin{array}{c}\text { At least 50 people } \\
\text { were killed }\end{array}$ \\
\hline 22 & $17 / 05 / 12$ & Plateau & $\begin{array}{c}130 \text { bodies found in Plateau were } \\
\text { presumed to be killed by boko Haram }\end{array}$ & \\
\hline 23 & $03 / 10 / 12$ & Mubi Nigeria & Massacred 25-26 people & 65 injured \\
\hline 24 & $18 / 03 / 13$ & Kano & Bus bombing 22 injured & 105 injured \\
\hline 25 & $07 / 05 / 13$ & Bama & Army Barrack prison 55 killed & 42 people killed \\
\hline 26 & $06 / 07 / 13$ & Yobe & School shooting & \\
\hline
\end{tabular}

Source: Retrieved from. "http://en. wikipedia.org/w/index.php?title=Boko Haram\&0ld=570146958"

TABLE 1b: Some of the update of the incidents of boko haram and military offensive in Northeast of Nigeria

\begin{tabular}{|c|c|c|c|c|}
\hline $\mathrm{S} / \mathrm{N}$ & Date & Place & Incident & Sources \\
\hline 1 & $27 / 08 / 13$ & $\begin{array}{l}\text { Maiduguri-- } \\
\text { Bama and } \\
\text { Damasak }\end{array}$ & Two Attacks 24 killed & $\begin{array}{c}\text { Retrieved from AFP News Agency www.afp } \\
\text { news,Tuesday AFP News, 27/08/13 }\end{array}$ \\
\hline 2 & 07/09/13 & Nigeria & 50 Boko Haram killes & $\begin{array}{l}\text { Timesofindia.indiatimes.com/topics/Boko-Haram } \\
07 / 09 / 13\end{array}$ \\
\hline 3 & $20 / 09 / 13$ & Abuja & $\begin{array}{c}\text { Opened fire on security } \\
\text { operatives near a legislative } \\
\text { building in Abuja }\end{array}$ & $\begin{array}{c}\text { www. telegraph co.uk/...Boko Haram-troops-in- } \\
\text { Abuja.gtm / 20/09/13 }\end{array}$ \\
\hline 4 & $29 / 9 / 13$ & $\begin{array}{c}\text { College of } \\
\text { Agriculture Gujba }\end{array}$ & 40 students & $\begin{array}{c}\text { Thisday Newspapper www.thisday,com } \\
29 / 09 / 13\end{array}$ \\
\hline 5 & $30 / 09 / 13$ & & 3 students killed & $\begin{array}{l}\text { Telegraph.co.uk-Boko Haram terrorists were } \\
\text { mistaken by students for soilders 30/09/13 }\end{array}$ \\
\hline 7 & $30 / 9 / 13$ & Highway road & 7 killed/burnt vehicle & $\begin{array}{c}\text { News24 Nigeria Retrieved from } \\
\text { www, news24.com.ng/Tags/companies/book haram } \\
\text { 30/09/13 }\end{array}$ \\
\hline 8 & $06 / 10 / 13$ & & 5 worshippers & $\begin{array}{c}\text { Retrieved From PM News Nigeria NG. } \\
\text { Pmnewsnigeria.com..../boko haram-kills-5- } \\
\text { worshppers-battles-military/-6/10/13 }\end{array}$ \\
\hline 9 & $16 / 10 / 13$ & borno & JTF Killed 40 b0k0 & $\begin{array}{c}\text { Leadership NEWSPAPER NG. Retrieved From } \\
\text { Leadership.ng/organization/boko haram }\end{array}$ \\
\hline 10 & $28 / 10 / 13$ & Cameroon border & 4 soldiers killed & $\begin{array}{l}\text { INFORMATIONNIGERIA Retrieved from, } \\
\text { www.informationng.com/tag/boko-haram 28/10/13 }\end{array}$ \\
\hline 11 & $26 / 10 / 13$ & $\begin{array}{l}\text { Nigeria, Yobe } \\
\text { NG. reteieved } \\
\text { from }\end{array}$ & 95 boko members killed & $\begin{array}{c}\text { Times of india } \\
\text { Timesofindia.indiatimes.com/topics/Boko-Haram } \\
\text { 26/10/13 }\end{array}$ \\
\hline 12 & \begin{tabular}{|c|}
$10-$ \\
$11 / 08 / 13$
\end{tabular} & Konduga Mosque & $\begin{array}{l}44 \text { worshippers shot dead } \\
\text { and } 12 \text { others }\end{array}$ & $\begin{array}{l}\text { Retrieved from AFP News Agency www.afp news } \\
\qquad 11 / 08 / 13\end{array}$ \\
\hline 13 & $16 / 10 / 13$ & Borno & 40 Boko haram Killed & $\begin{array}{c}\text { Leadership.ng/news/...jtf-kills-40-boko haram } \\
\text { insurgents- borno-operation-0-16/10/13 }\end{array}$ \\
\hline 14 & 29/10/13 & Yobe damaturu & 128 Boko killed & $\begin{array}{l}\text { The Nation retrieved from } w w w \text {. thenation.com } \\
\qquad 29 / 10 / 13\end{array}$ \\
\hline 15 & $9 / 10 / 13$ & borno & 200 houses destroyed & Daily Post Nigeria dailypost.com.ng/.../09/10/13 \\
\hline 16 & $\begin{array}{l}\text { Sept. } \\
2013\end{array}$ & Nigeria & $\begin{array}{c}195 \text { killed by roadside attacks } \\
\text { in Northern Nigeria }\end{array}$ & $\begin{array}{l}\text { Telegraph.co.uk- Suspected Boko Haram gunmen } \\
\text { killed } 195 \ldots 20 / 10 / 13\end{array}$ \\
\hline
\end{tabular}

Sources: See references as in remark Column in the table 1b. 